\title{
9. NORTHWARD MOTION OF THE ONTONG-JAVA PLATEAU BETWEEN -110 AND -30 M.Y.: A PALEOMAGNETIC INVESTIGATION OF DSDP SITE 289
}

\author{
S.R. Hammond, L.W. Kroenke, and F. Theyer, Hawaii Institute of Geophysics, \\ University of Hawaii, Honolulu, Hawaii
}

\section{INTRODUCTION}

The only site selected for paleomagnetic investigation during the Leg 30 cruise of D/V Glomar Challenger was Site 289 on the Ontong-Java Plateau. Continuous coring was planned at Site 289 in expectation of encountering a continuous sequence of biogenic sediments at least as old as middle Eocene, and perhaps even older, based on coring results at Site 288. The objectives of the paleomagnetic study were to determine the paleolatitude of the site at the time of plateau formation and to discern any subsequent northward or southward motion of the plateau. Kroenke (1972a, b) has discussed the formation of the plateau and concluded that it originated through accumulation of flood basalts along an eastwest aligned spreading ridge, with formation of the southern margin during Late Cretaceous time.

Nearly all the sediment samples used in the present study proved to be siliceous limestones having very weak magnetic remanence. Thus, in addition to the objectives mentioned above, the results presented here demonstrate the feasibility of obtaining geologically meaningful paleomagnetic information from such deepsea carbonates.

\section{METHODS}

Samples removed from the cores were trimmed to cubes measuring slightly more than $2 \mathrm{~cm}$ on a side. Precautions were taken to avoid drilling disturbances and to ascertain that bedding was horizontal in the sampled sections. The samples were kept moist until they were analyzed.

Remanence of the sediment samples was measured with a Superconducting Technology, Inc., cryogenic rock-magnetometer. The basalts were measured using a modified Foster-type $5-\mathrm{Hz}$ spinner magnetometer. All of the samples in the present study were subjected to alternating field (AF) partial demagnetization analysis subsequent to measurement of their natural remanent magnetization (NRM). The device used to demagnetize the sediments utilizes a two-axis sample tumbler and a $400-\mathrm{Hz}$ alternating field. Demagnetization of these samples was carried out in a shielded room containing an ambient field of about 200 gammas. The basalts were demagnetized in the earth's field using a four-axis tumbler and a $60-\mathrm{Hz}$ alternating field. For most of the samples the AF strength was increased to 300 oe by steps of 25 oe (Figures 1 and 2). The results of the measurements are presented in Tables 1 and 2 .

Inclination values are relative to horizontal; positive values indicate downward direction. Paleolatitudes, corresponding to individual sample inclination values following demagnetization, were derived using the dipole formula. Declination values are relative to the split

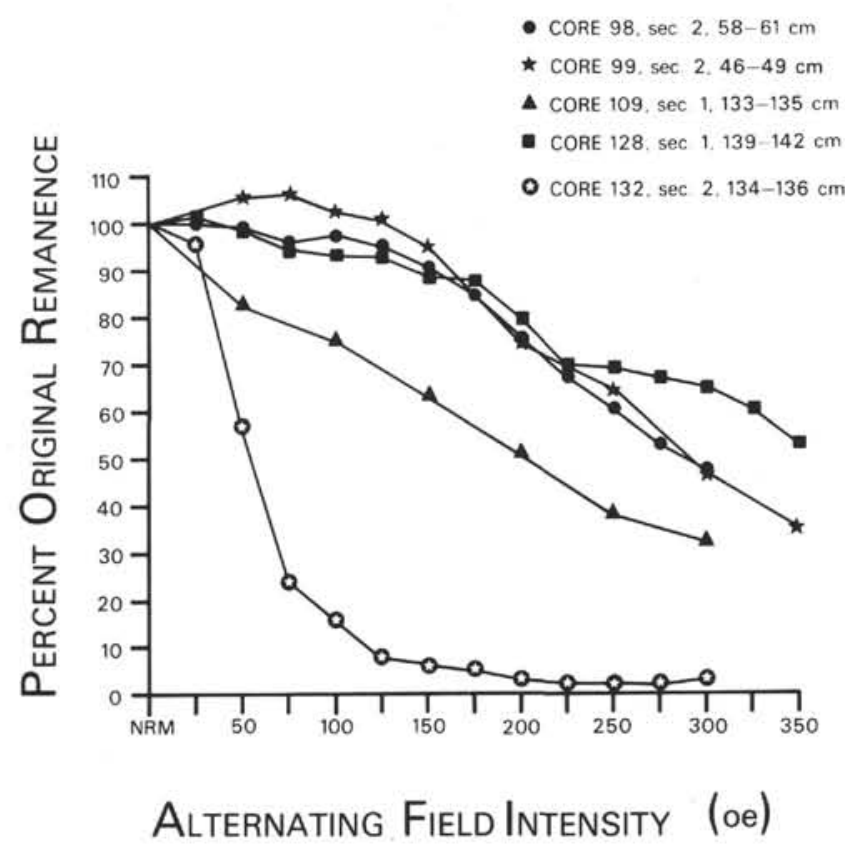

Figure 1. Sample intensity versus peak demagnetization field intensity.
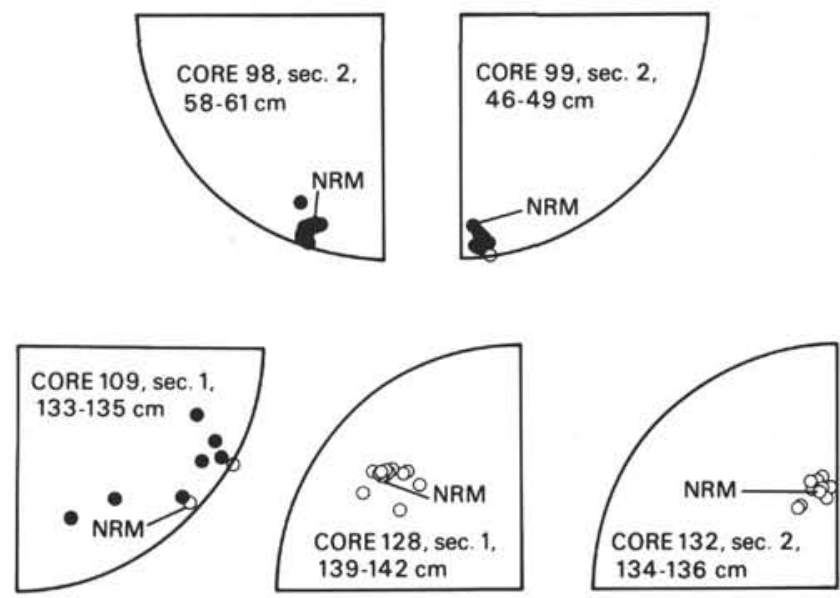

Figure 2. Wulf stereographic projections (for the samples in Figure 1) showing the relative change in position of the paleomagnetic vector in response to stepwise partial alternating field demagnetization.

faces of the cores and may not be internally consistent within a core due to the possibility of horizontal rotation of the sediments during drilling. The maximum difference in intensity of magnetization between replicate measurements of individual samples was $7 \%$ (at the 100 - 
TABLE 1

Paleomagnetic Measurements of Sediment Samples From Site $289^{\mathrm{a}}$

\begin{tabular}{|c|c|c|c|c|c|}
\hline $\begin{array}{c}\text { Sample } \\
\text { (Interval in } \mathrm{cm} \text { ) }\end{array}$ & $\begin{array}{l}\text { Incl. } \\
\left({ }^{\circ}\right)\end{array}$ & $\begin{array}{c}\text { Decl. } \\
\left({ }^{\circ}\right)\end{array}$ & $\begin{array}{c}\text { Intensity } \\
\left(10^{-7}\right. \\
\text { emu/cc })\end{array}$ & $\begin{array}{c}\text { Approx. } \\
\text { Age } \\
\text { (m.y.B.P.) }\end{array}$ & $\begin{array}{l}\text { Paleo- } \\
\text { latitude } \\
\left(^{\circ}\right)\end{array}$ \\
\hline $98-2,58-61$ & $\begin{array}{l}7.3 \\
4.0\end{array}$ & $\begin{array}{l}198.3 \\
199.1\end{array}$ & $\begin{array}{l}16.0 \\
15.6\end{array}$ & 31.5 & 2.0 \\
\hline $99-2,46-49$ & $\begin{array}{l}6.5 \\
2.3\end{array}$ & $\begin{array}{l}175.7 \\
173.0\end{array}$ & $\begin{array}{l}9.2 \\
9.4\end{array}$ & 32 & 1.1 \\
\hline $101-2,111-114$ & $\begin{array}{l}-5.2 \\
-1.6\end{array}$ & $\begin{array}{l}159.8 \\
161.2\end{array}$ & $\begin{array}{l}1.4 \\
1.2\end{array}$ & 34 & 0.8 \\
\hline $102-1,145-148$ & $\begin{array}{l}3.0 \\
5.5\end{array}$ & $\begin{array}{l}209.6 \\
205.0\end{array}$ & $\begin{array}{l}2.1 \\
2.1\end{array}$ & 40 & 2.8 \\
\hline $103-1,144-147$ & $\begin{array}{r}-5.7 \\
3.6\end{array}$ & $\begin{array}{l}206.8 \\
212.9\end{array}$ & $\begin{array}{l}1.2 \\
1.4\end{array}$ & 41 & 1.8 \\
\hline $106-2,43-46$ & $\begin{array}{l}-3.0 \\
-6.6\end{array}$ & $\begin{array}{l}254.0 \\
254.2\end{array}$ & $\begin{array}{l}0.8 \\
0.7\end{array}$ & 42 & 3.3 \\
\hline $107-2,23-26$ & $\begin{array}{r}-3.3 \\
8.3\end{array}$ & $\begin{array}{l}114.6 \\
105.0\end{array}$ & $\begin{array}{l}1.2 \\
1.0\end{array}$ & 42.5 & 4.2 \\
\hline $108-1,52-54^{b}$ & $\begin{array}{l}1.9 \\
4.4\end{array}$ & $\begin{array}{l}217.1 \\
235.1\end{array}$ & $\begin{array}{l}0.6 \\
0.7\end{array}$ & 43 & 2.2 \\
\hline $109-1,133-135$ & $\begin{array}{r}-2.7 \\
6.4\end{array}$ & $\begin{array}{l}131.5 \\
115.0\end{array}$ & $\begin{array}{l}1.3 \\
0.8\end{array}$ & 44 & 3.2 \\
\hline $110-1,132-135$ & $\begin{array}{l}8.3 \\
8.2\end{array}$ & $\begin{array}{l}261.6 \\
264.7\end{array}$ & $\begin{array}{l}1.4 \\
1.3\end{array}$ & 44.5 & 4.1 \\
\hline $111-3,123-125$ & $\begin{array}{r}3.9 \\
12.1\end{array}$ & $\begin{array}{l}243.4 \\
228.1\end{array}$ & $\begin{array}{l}0.6 \\
0.8\end{array}$ & 46 & 6.1 \\
\hline $113-1,105-108$ & $\begin{array}{r}8.7 \\
10.1\end{array}$ & $\begin{array}{l}189.8 \\
182.1\end{array}$ & $\begin{array}{l}0.6 \\
0.9\end{array}$ & 47 & 5.1 \\
\hline $115-1,87-90$ & $\begin{array}{l}11.1 \\
10.5\end{array}$ & $\begin{array}{l}248.2 \\
260.9\end{array}$ & $\begin{array}{l}1.0 \\
1.2\end{array}$ & 51.2 & 5.3 \\
\hline $116-1,116-119$ & $\begin{array}{l}36.3 \\
11.0\end{array}$ & $\begin{array}{l}216.5 \\
209.9\end{array}$ & $\begin{array}{l}0.4 \\
0.5\end{array}$ & 55 & 5.6 \\
\hline $118-1,70-73^{b}$ & $\begin{array}{r}24.8 \\
0.0\end{array}$ & $\begin{array}{l}242.5 \\
203.7\end{array}$ & $\begin{array}{l}0.3 \\
0.2\end{array}$ & 57 & 0.0 \\
\hline $120-1,107-110^{b}$ & $\begin{array}{l}41.6 \\
81.0\end{array}$ & $\begin{array}{l}360.0 \\
344.1\end{array}$ & $\begin{array}{l}0.6 \\
0.5\end{array}$ & 57.7 & 72.4 \\
\hline $121-2,76-78$ & $\begin{array}{l}15.8 \\
12.1\end{array}$ & $\begin{array}{l}335.9 \\
339.6\end{array}$ & $\begin{array}{l}3.7 \\
4.0\end{array}$ & 63 & 6.1 \\
\hline $122-2,81-84$ & $\begin{array}{l}24.0 \\
18.8\end{array}$ & $\begin{array}{l}257.9 \\
247.5\end{array}$ & $\begin{array}{l}1.6 \\
1.2\end{array}$ & 66.5 & 9.7 \\
\hline $123-1,97-100$ & $\begin{array}{l}35.8 \\
20.9\end{array}$ & $\begin{array}{l}163.1 \\
171.7\end{array}$ & $\begin{array}{l}1.3 \\
1.0\end{array}$ & 67 & 10.8 \\
\hline $124-2,104-107$ & $\begin{array}{l}14.1 \\
17.4\end{array}$ & $\begin{array}{l}203.4 \\
201.7\end{array}$ & $\begin{array}{l}1.0 \\
0.9\end{array}$ & 67.5 & 8.9 \\
\hline $125-1,138-141$ & $\begin{array}{l}30.0 \\
20.4\end{array}$ & $\begin{array}{l}158.2 \\
149.3\end{array}$ & $\begin{array}{l}0.6 \\
0.5\end{array}$ & 68 & 10.5 \\
\hline $128-1,139-142$ & $\begin{array}{l}-17.5 \\
-16.8\end{array}$ & $\begin{array}{l}310.1 \\
308.6\end{array}$ & $\begin{array}{l}10.8 \\
10.1\end{array}$ & 69.5 & 8.6 \\
\hline $131-1,32-34$ & $\begin{array}{l}-28.2 \\
-35.1\end{array}$ & $\begin{array}{l}359.9 \\
359.4\end{array}$ & $\begin{array}{l}5.6 \\
4.9\end{array}$ & 106.2 & 19.4 \\
\hline $131-1,107-110$ & $\begin{array}{r}-1.5 \\
-45.3\end{array}$ & $\begin{array}{l}274.9 \\
264.8\end{array}$ & $\begin{array}{r}538.4 \\
94.3\end{array}$ & 106.5 & 26.8 \\
\hline $131-2,45-47$ & $\begin{array}{l}-20.0 \\
-42.6\end{array}$ & $\begin{array}{l}108.3 \\
108.1\end{array}$ & $\begin{array}{r}111.8 \\
41.7\end{array}$ & 107.0 & 24.6 \\
\hline $131-3,38-40$ & $\begin{array}{l}-13.5 \\
-47.5\end{array}$ & $\begin{array}{l}139.4 \\
150.7\end{array}$ & $\begin{array}{l}741.8 \\
158.3\end{array}$ & 107.5 & 28.6 \\
\hline
\end{tabular}

${ }^{\text {a }}$ The first row of data for each sample refers to NRM; the second row contains the results following partial AF demagnetization at 100 oe. ${ }^{b}$ Data possibly unreliable on the basis of stepwise demagnetization results. 
TABLE 2

Paleomagnetic Measurements of Basalt Samples From Site $289^{\mathrm{a}}$

\begin{tabular}{lrrccc}
\hline $\begin{array}{c}\text { Sample } \\
(\text { Interval in cm) }\end{array}$ & \multicolumn{1}{c}{$\begin{array}{c}\text { Incl. } \\
\left.{ }^{\circ}\right)\end{array}$} & \multicolumn{1}{c}{$\begin{array}{c}\text { Decl. } \\
\left({ }^{\circ}\right)\end{array}$} & $\begin{array}{c}\text { Intensity } \\
\left(10^{-2}\right. \\
\text { emu/cc })\end{array}$ & $\begin{array}{c}\text { Depth From } \\
\text { Top of Hole } \\
(\mathrm{m})\end{array}$ & $\begin{array}{c}\text { Paleo- } \\
\text { latitude } \\
\left({ }^{\circ}\right)\end{array}$ \\
\hline $132-2,134-136$ & -46.4 & 351.8 & 2.5 & 1262.4 & 30.3 \\
& -49.4 & 335.9 & 0.1 & & \\
$132-3,95-97$ & -55.4 & 222.0 & 2.5 & 1263.5 & 32.7 \\
& -52.1 & 220.6 & 0.5 & & \\
$132-3,128-130$ & -66.9 & 154.5 & 1.7 & 1263.8 & 34.9 \\
& -54.4 & 160.6 & 0.1 & & \\
$132-4,85-87$ & -50.8 & 84.6 & 2.8 & 1264.9 & 31.3 \\
& -50.6 & 94.9 & 0.1 & & \\
$132-4,115-117$ & -51.5 & 190.5 & 2.0 & 1265.2 & 31.7 \\
& -51.0 & 192.5 & 0.7 & & \\
$132-4,141-143^{\mathrm{b}}$ & -6.6 & 130.6 & 2.5 & 1265.4 & 15.6 \\
& -29.2 & 134.8 & 0.4 & & \\
$133-1,127-129$ & -52.4 & 49.5 & 1.9 & 1270.3 & 34.0 \\
& -53.4 & 50.0 & 0.4 & & \\
\hline
\end{tabular}

\footnotetext{
${ }^{\mathrm{a}}$ The first row of data for each sample refers to NRM; the second row of paleomagnetic data for each sample contains the results following partial AF demagnetization at 175 oe.

${ }^{b}$ Data possibly unreliable on the basis of stepwise demagnetization results.
}

oe level) while the corresponding angular deviations typically did not exceed $2^{\circ}$ and were never more than $5^{\circ}$.

The ages assigned to the present sediment samples (Table 1; Figure 3) were obtained by using the preliminary biostratigraphic summary of Site 289 prepared by the shipboard paleontologists (elsewhere in this volume) and interpolating individual ages on the basis of each sample's level in the cores. It should therefore be emphasized that the stratigraphic ages are preliminary.

In the following discussion, crustal motion indicated by paleomagnetic results is described relative to an assumed geocentric axial dipole.

\section{DISCUSSION}

The preliminary results discussed here are part of a paleomagnetic investigation which will ultimately in clude virtually the entire stratigraphic section drilled at Site 289. To date, 26 sediment samples have been measured along with 7 samples of the underlying basalt. The latter are treated here as multiple samples from a single flow in accordance with the interpretation presented in the Site 289 report. Considered as such, the paleolatitudes for the basalt samples have a mean of about $32^{\circ}$ (excluding one sample on the basis of its response to partial AF demagnetization; see Table 2). The Aptian age of the overlying sediments and a lack of stratigraphic evidence for a long hiatus at the basaltsediment interface suggest that the basalt is of Early Cretaceous age. In Figure 3, the age of the basalt is tentatively estimated to be 109 m.y.

Figure 3 reveals a trend of increasing paleolatitude with increasing age for the sediment samples in the interval between about -30 and -70 m.y. The lack of paleomagnetic data between about -70 and -105 m.y. is the result of a late Aptian to middle Campanian hiatus in the hole. The fact that the paleolatitude values are offset at this stratigraphic break would seem to imply that the systematic trend in paleolatitudes is the result of plate motion rather than, for instance, either a progressive chemical alteration of the magnetic remanence or a compaction effect.

A rate of motion of about $2.5 \mathrm{~cm} / \mathrm{yr}$ is indicated by the slope of the linear least-squares fitted line for the sediments in the time span between about -30 and -70 m.y. (Figure 3). But in view of the limited data and the considerable length of time that they span, such a constant-rate interpretation must be regarded as only approximate.

If the best-fit line is extrapolated beyond -70 m.y. to about -110 m.y., the resulting paleolatitudes would be considerably less than the actual measured values of the oldest sediments and the basalt. Hence, there must have been a more rapid spreading rate during all or part of the time prior to -70 m.y. The suggestions by Larson and Pitman (1972) and Hays and Pitman (1973) that the Cretaceous was a time of rapid sea-floor spreading might support this conclusion. However, there are even fewer data for this Aptian interval (Table 1; Figure 3) than for the Paleogene, and our cautionary statements about the younger interval apply even more strongly here.

Because the sediment magnetostratigraphy has not as yet been correlated to an established geomagnetic time scale, it is not possible to state categorically that the negative inclination values in the sediment data correspond to normal field polarity (and the positive to reversed). It cannot be stated unequivocally, therefore, that the sediments were deposited in the Southern Hemisphere and that the direction of plate motion was to the north. Tectonic evidence supporting the hypothesis that the Pacific plate has been moving 


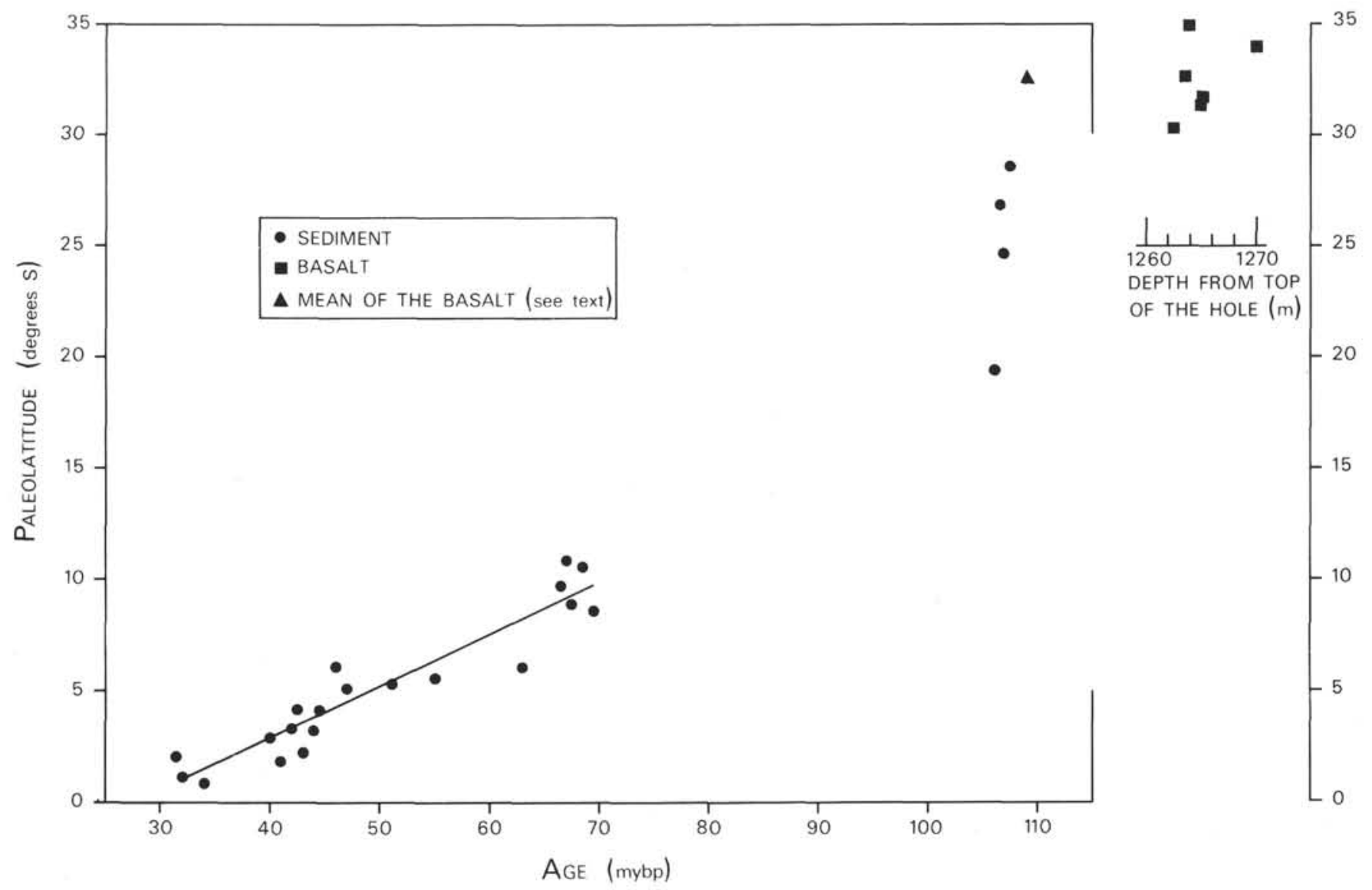

Figure 3. Paleolatitude versus age for sediments and versus depth in the hole for basalts (squares) at Site 289.

northward at varying rates, both during and since Cretaceous time, is substantial, however, and includes results of paleomagnetic studies of DSDP cores (Sclater and Cox, 1970; Sclater and Jarrard, 1971; Jarrard, 1973). Hammond et al. (1974) and Theyer and Hammond (1974) report corroborating evidence from their paleomagnetic studies of piston cores from the central Pacific Basin, i.e., that although the rate did vary, the central Pacific lithosphere continuously moved northward throughout the latest Paleogene and the entire Neogene.

In conclusion, the most plausible interpretation of the present results appears now to be that the Ontong-Java Plateau has moved northward by about $32^{\circ}$ since its formation, and reached its present latitude by about -30 m.y. If such is the case, there must have been complete decoupling of the plateau from the central portion of the Pacific plate subsequent to about -30 m.y.

\section{ACKNOWLEDGMENTS}

We should like to express our gratitude to C.E. Helsley for his assistance and permission to use the cryogenic rock-magnetometer at the University of Texas at Dallas. We also thank R.M. Moberly for his many helpful suggestions. This work was supported by ONR Contract NOOO14-70-A-0016-0001.

\section{REFERENCES}

Hammond, S.R., Theyer, F., and Sutton, G.H., 1974. Paleomagnetic evidence of northward movement of the Pacific plate in deep-sea cores from the Central Pacific Basin: Earth. Planet. Sci. Lett., v. 22, p. 22-28.

Hays, J.D. and Pitman, W.C., III, 1973. Lithospheric plate motion, sea level changes and climatic and ecological consequences: Nature, v. 246, p. 18-22.

Jarrard, R.D., 1973. Paleomagnetism of Leg 17 sediment cores. In Winterer, E.., Ewing, J.I., et al., Initial Reports of the Deep Sea Drilling Project, Volume 17: Washington (U.S. Government Printing Office), p. 365-375.

Kroenke, L.W., 1972a. Geology of the Ontong-Java Plateau: Hawaii Inst. Geophys. Rept., HIG-72-5. 1972b. Possible occurrence of extensive flood basalts within the ocean basins: Meeting Cordilleran Section Geol. Soc. Am. 68th (Abstract), v. 4, p. 185-186.

Larson, R.L. and Pitman, W.C., III, 1972. World-wide correlation of Mesozoic magnetic anomalies: Geol. Soc. Am. Bull., v. 83, p. 3645-3662.

Sclater, J.G. and Cox, A., 1970. Paleolatitudes from JOIDES deep sea sediment cores: Nature, v. 226, p. 934-935.

Sclater, J.G. and Jarrard, R.D., 1971. Preliminary paleomagnetic results, Leg 7. In Winterer, E.L., Riedel, W.R., et al., Initial Reports of the Deep Sea Drilling Project, Volume 7: Washington (U.S. Government Printing Office), p. 1227-1234.

Theyer, F. and Hammond, S. R., 1974. The Cenozoic magnetic time scale in deep-sea cores: completion of the Neogene: Geology, v. 2, p. 487-492. 